\title{
ANALYSIS OF THE HUNGARIAN STRATEGIC MANAGEMENT CONSULTING MARKET
}

\author{
ROLAND SCHMUCK ${ }^{1}$ \\ University of Pécs (Hungary)
}

\begin{abstract}
Many Hungarian small and medium enterprises are facing problems using management methodologies. Strategic management consulting is a common type of business consulting and is one of the most important in the field. The article analyses two previous Hungarian surveys with the aim of better understanding the market. Two surveys are compared with each other and the size of the Hungarian strategic consulting market is calculated based on secondary data. Trends and problems in the industry are also described briefly. The findings of this paper help to better understand what is happening in the industry.

KEYWORDS: strategy, management, consulting, Hungary.
\end{abstract}

JEL CODES: L10, L21, M21.

DOI:

\section{Introduction}

Most of the Hungarian businesses are small and medium enterprises (SMEs) which were founded after the change of the regime in Hungary in 1989. The problem is that many of these companies have grown in the last decades solely by the knowledge and personal connections of their founder and owner, therefore, they lack the appropriate management knowledge. There is an urgent need for them to change their management and use strategic management methodologies so that to develop further. Strategic management consulting can help them to achieve their goals.

The purpose of this paper is to highlight the strategic consulting management market in Hungary. This issue is worth researching because many Eastern European countries are in a similar economic situation where SMEs are facing much the same problems as in Hungary.

The object of the research is to analyse the Hungarian strategic consulting industry after a brief introduction of strategic consulting as a service. It shows the state, market size and market trends of the Hungarian strategic management consulting sector. There is not much information available in this market niche. The research questions are the following:

- What is the market size of the Hungarian strategic management consulting market?

- What are the main trends in the Hungarian strategic management consulting market?

The article presents new data by comparing previous surveys and the author gives his own calculation how to estimate size of the Hungarian strategic consulting market.

Roland Schmuck - dr., assistant professor at the Department of Leadership and Organizational Sciences, Faculty of Business and Economics, University of Pécs, Hungary

Research interests: strategic management, change management, business consulting and quality assurance

E-mail: schmuck@ktk.pte.hu

Tel. +36 72501599 / 23369 
The main task of the research is to describe strategic management and separate it from strategic planning as an outdated discipline. The literature review consists only of particular parts of scientific literature which can serve as the basis for this research. Next to international strategic management books, several books and articles on the Hungarian business consulting are also reviewed. The paper addresses to activity of strategic consultants, pointing out the main problems which they are coping with. In the main part of the research previously published data is analysed. Then, two research surveys of third-party are presented and analysed in the view of strategic consulting.

\section{Planning and implementing strategies}

Companies need strategies to cope with competition. A traditional method of strategic creation is strategic planning which is planning of company goals under static or slowly changing corporate environmental conditions (Barakonyi, 1999). Strategy can be divided into functional strategies or geographical strategies (Bartek et al., 2007). The external environment changes are so sharp nowadays that the environment should be taken into consideration as well. This evolved strategic planning into strategic management and it became an important issue in the life of companies (Barakonyi, 2000). Strategic management is an art and science of formulating, implementing and evaluating cross-functional decisions that enable an organization to achieve its objectives. Because of this strategic management integrates management and other functional areas of the company (David, 2013). A great strategy is a good start for your business, but it does not mean that it is easy to follow and you will be competitive just by using appropriate planning techniques. Implementing is also a very important issue but unfortunately most companies struggle with implementation (Neilson et al., 2008). Strategic management emphasizes long-term performance over short-term. Only 13 companies have survived so far from the original Forbes 100 companies listed in 1917. To be able to succeed in long-term companies have to adopt to new and changing market trends (Wheelen, Hunger, 2012).

Arnoldo Hax, Alfred P. Sloan, professor of management, states that "Strategic Management and Consulting deals centrally with these two issues: deciding what to do, which is the heart of strategy formulation; and making it happen, which is the concern of strategy implementation.” (MIT, 2004: 1)

A joint study by Renaissance Solutions, Inc., CFO magazine, and Business Intelligence describes the critical factors to implement strategies (CFO, Business Intelligence, 1996). Most of the companies are unable to implement their strategies. What can be the reasons? The above mentioned article describes them in details:

- Awareness: $95 \%$ of the typical workforce does not understand the strategy.

- Financial resources: $60 \%$ of organizations do not link budgets to strategy.

- Governance: $44 \%$ of board directors cannot identify the key drivers of value in the companies they govern.

- Executive agenda: $85 \%$ of executive teams spend less than one hour per month discussing strategy.

- Incentives; $70 \%$ of organizations do not link middle management incentives to strategy.

- People: 55\% of human resources (HR) organizations either interpret strategy or deal only with operational priorities (CFO, Business Intelligence 1996).

The survey of Monitor Analysis, which involved 354 company executives, shows that the leaders of companies consider one of the most important business challenge to implement the strategy. Leaders noticed the problem and many of them started initiatives to better formalize and implement the company strategy (Provice, 2017).

The BSCOL Research Survey states that $70 \%$ of companies with formalized strategic implementation processes have better performance than companies without using these management practices (Provice, 2017). The key is to make sure companies can effectively execute the right things. As the proverb says: "The main thing is to keep the main thing the main thing" (Covey et al., 1994).

Strategic planners are those people in an organization who are specialized on ensuring the organization to have and implement an appropriate strategy. Strategy is developed with consensus of strategic planners and management of an organization. After the strategic plan is ready it has to be communicated within the organization. If the organization uses the strategy consequently in its decisions the strategy will most probably be implemented (Arnold, Bernstein, 2006). 


\section{The role of strategic management consulting}

The "product" of consultant companies is intellectual property of their consultants which is actually the accumulation of special skills and knowledge. Consulting is a service where consultants stimulate their clients to make changes. No one knows about the future success, but the previous knowledge of consultants can give some guarantee on good ideas and proposals. Consultants should be ready to handle unexpected situations in strong cooperation with the organization. Consultant is a helper hand for the organization (Biswas, Twitchell, 2006)

Consultants who concern themselves with issues like basic goals or mission, business policy and strategy, planning, structuring and control of an organization are strategic or general management consultants. They are different than those consultants who consult in a specialized functional area like finance or marketing (Kubr, 2002). Companies with deterioration results, in crisis or near crisis may need the help of such consultants. In these cases the top management may be out of ideas where the company is heading and what to do. In other cases the management may have the goals but they are unable to implement the strategies (Kubr, 2002).

Strategic consulting is part of management consulting, so the features of management consulting applies to this type of consulting as well:

- Management consulting should be done on base of a contract.

- Consultants are independent of that company which receives the consulting activity.

- Consultants should not decide on their ideas and proposals.

- Consultants should only cooperate in implementing their proposals if they are asked to do that (Hoványi, 1997).

Table 1. Typical goals of strategic planners

\begin{tabular}{|l|l|}
\hline Goal and function of strategic planning & Description \\
\hline Proposal & $\begin{array}{l}\text { Informing the top management of proposed strategic steps } \\
\text { with the help of analysis }\end{array}$ \\
\hline Determinate course line & $\begin{array}{l}\text { Facilitate competitive short-, middle-, or long-term } \\
\text { strategies with the help of company ideas and analysis. } \\
\text { It can be implemented through three methods: top-down, } \\
\text { down-top, hybrid of the two }\end{array}$ \\
\hline Motivational paradigm shift & $\begin{array}{l}\text { Raising provocative business ideas motivating managers to } \\
\text { prescind ordinary strategies and tactics }\end{array}$ \\
\hline Analyse strategic business information & $\begin{array}{l}\text { Analysing information to help the work of top } \\
\text { management }\end{array}$ \\
\hline Encouragement and motivation & $\begin{array}{l}\text { Persuasion of the affected groups within the organization } \\
\text { and motivate them to use business ideas }\end{array}$ \\
\hline Provide intellectual property to business decisions & $\begin{array}{l}\text { Creating of databases and make analyses to support } \\
\text { management decisions in mainly those cases which are } \\
\text { important in a strategic view (e.g. company acquisitions } \\
\text { and fusions) }\end{array}$ \\
\hline “Think tank" or inexhaustible storehouse of ideas & $\begin{array}{l}\text { Creating of analyses and definition of statements to solve } \\
\text { business problems }\end{array}$ \\
\hline
\end{tabular}

Source: C. Arnold, S. C. Bernstein (2006: 94).

Consultants need to use change management techniques. Any consultant service include changes in the organization - let it be strategic plan or business process reengineering (Maira, Little 2006). There is usually no guarantee that the proposals of the consultant will work. However, E. Biech suggests that consultants should offer 100\% money-back guarantee for the work done (Biech, 2006).

Strategic consultant concentrates on the five main subjects of the strategic consulting progress as can be seen in Figure 1. 


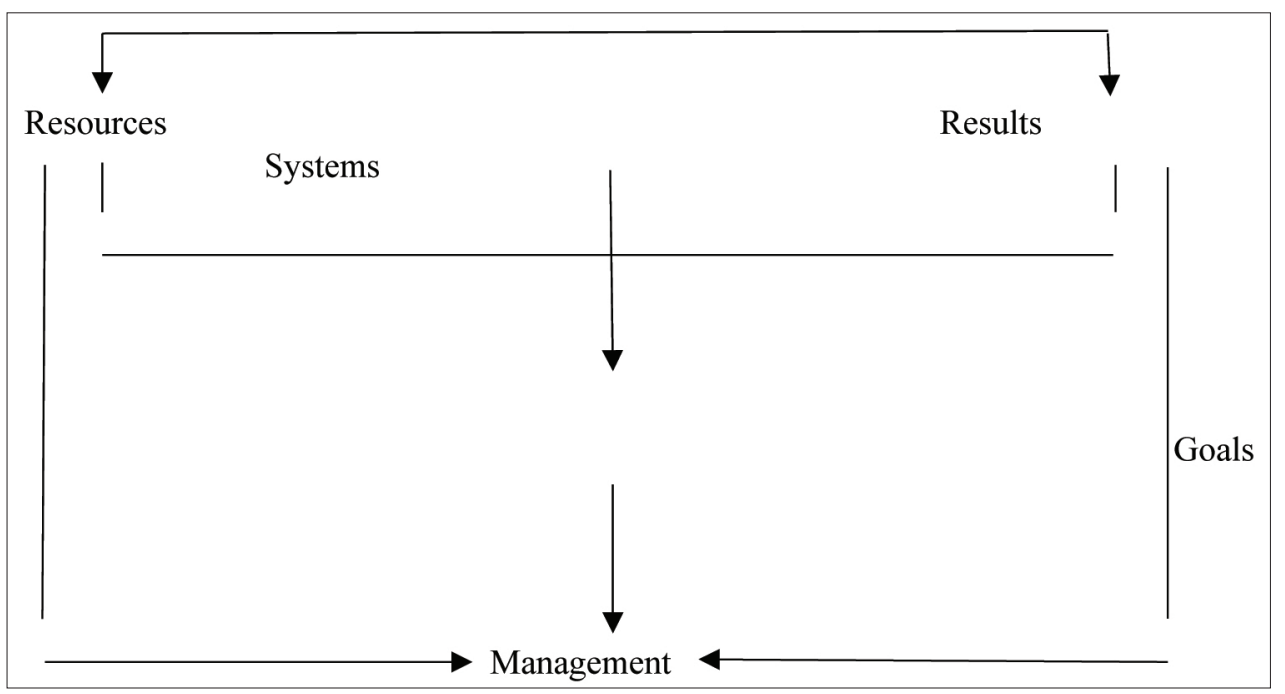

Figure 1. Five main issues of strategic consulting

Source: G. Hoványi (1997: 68).

Ordinary company resources are capital, technology, human resources and natural resources. In a modern view, these resources can be extended by six other resources: information, innovation potential, coordination, immaterial resources, fit in the vertical value chain and time (Hoványi, 1999).

Systems stand for the functional parts and their cooperation inside the company. Companies are built up of smaller subsystems which should be synchronized with each other.

In case of results the most important are the quantified results which may be included in the company balance sheet and income statement. Consulting should help to develop the company in measurable results.

Results are directly connected to goals. Managers should have specified goals for the whole company and for the company subsystems as well. Goals may be outside the company as well: some organizations have social goals to achieve next to their own goals (Hoványi, 1999).

Strategic consultants should help the company to reach competitive advantages. This can be based on company resources, systems, goals, results or leadership. The realized competitive advantage always depends on the features of the company and the environment, the strong and weak points of the competitors. Competitive advantage should be built in fields which are durable and the skill developing costs are low compared to the positive outcome of the advantage (Hoványi, 1999).

\section{The strategic management consulting market in Hungary}

In this chapter two research surveys performed by the Szent István University and the Consulting Roundtable are presented and analysed (Poór, 2014; 2015).

The Hungarian consulting market is over the financial crisis and it already started to develop slowly (Budapesti Kereskedelmi és Iparkamara, 2014). However most of the information available is about business consulting market itself. There is a lack of detailed information on the strategic management consulting market. To describe the state of strategic management consulting in Hungary in this section I compare two surveys and show the available information on the market size which makes possible to calculate the strategic management consulting market in Hungary. 


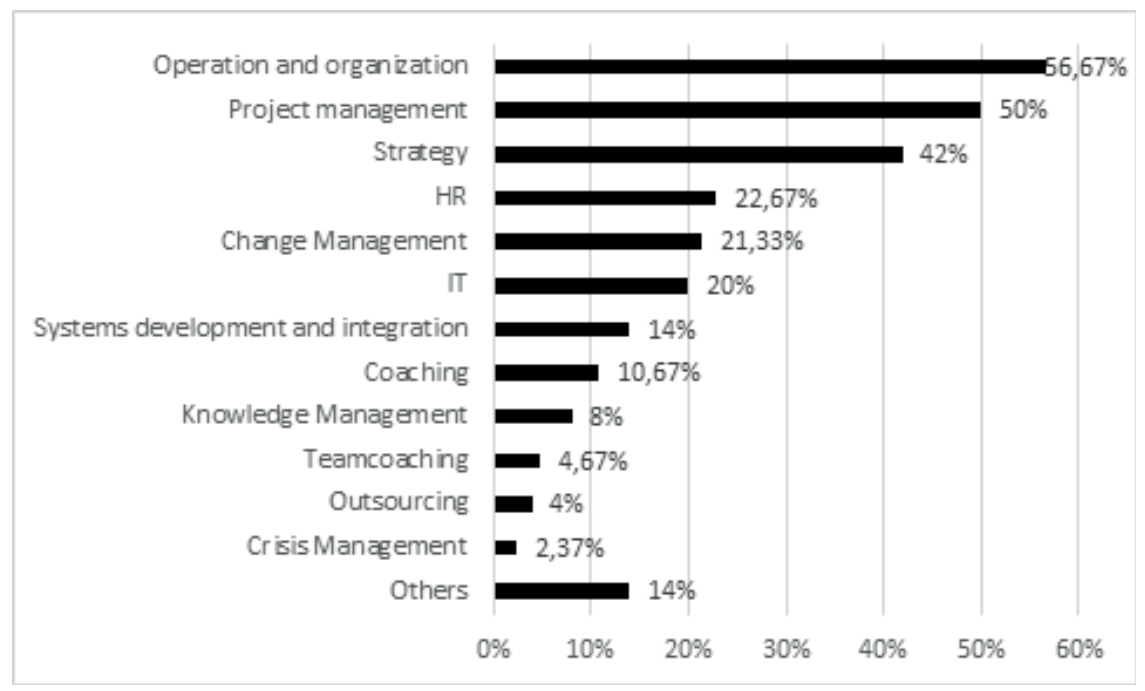

Figure 2. Most common business consulting activities in Hungary in 2014

Source: J. Poór (2014: 10).

The total income of the consulting market can only be estimated. An estimation based on the members of the Hungarian Association of Management Consultants (VTMSZ) ${ }^{2}$ is that the total consulting market is about 50.000.000.000 Hungarian Forints (which equals about 161 million Euros ${ }^{3}$ ). From this value approximately 23.500.000.000 Hungarian Forints (about 76 million Euros) is the market of management consulting (Vicze, 2014).

Most of the VTMSZ member companies are small, with less than 10 employees. Instead of the smaller size companies VTMSZ members cope with minimum three consulting fields (Vicze, 2014). Companies coping only with strategic management problems are very rare, or may not be existing at all in Hungary.

In the following part there are two surveys shown with the goal to reanalyse the data and show trends. The survey of Szent István University and the Consulting Roundtable shows the frequency of different types of business consulting. There were 150 questionnaires answered by Hungarian companies in the survey. Each company could give up to three answers. The most common business consulting activities are operation and organization (56.67\%), project management (50\%) and strategic consulting (42\%) (Poór, 2014).

The above mentioned survey shows that the most common activity in Hungary after the financial crisis was to start new activities and the second most common activity was to redefine the strategy of the company (Poór, 2014). The companies were asked about which consultancy field is increasing or decreasing by their opinions. Use of the consulting services show that strategic and HR consulting activity declined the most. This can mean that the market of these consulting services became saturated.

A similar survey was done in 2015. In this survey 130 companies answered the questions. Hungarian companies could give up to three answers to the most common consulting activities used. Unfortunately the report of the research only gives relative numbers to each other which is not directly comparable to the 2014 numbers. In this survey the most used consulting services in Hungary are operations (20\%), strategy (15\%) and project management (15\%). The order is similar to the survey of 2014 (Poór, 2015).

Based on the survey, strategic consulting includes development of strategic planning, fusions, acquisitions, and sales and marketing.

To answer the first research question we need to compare the 2014 and 2015 surveys. The surveys are not directly comparable, so I recalculated the 2014 survey results in relative form such as the data available from the 2015 survey. The results confirm the prediction of the 2014 survey: strategic consulting is decrea-

Vezetési Tanácsadók Magyarországi Szövetsége: www.vtmsz.hu

1 Euros $=310$ Hungarian Forints 


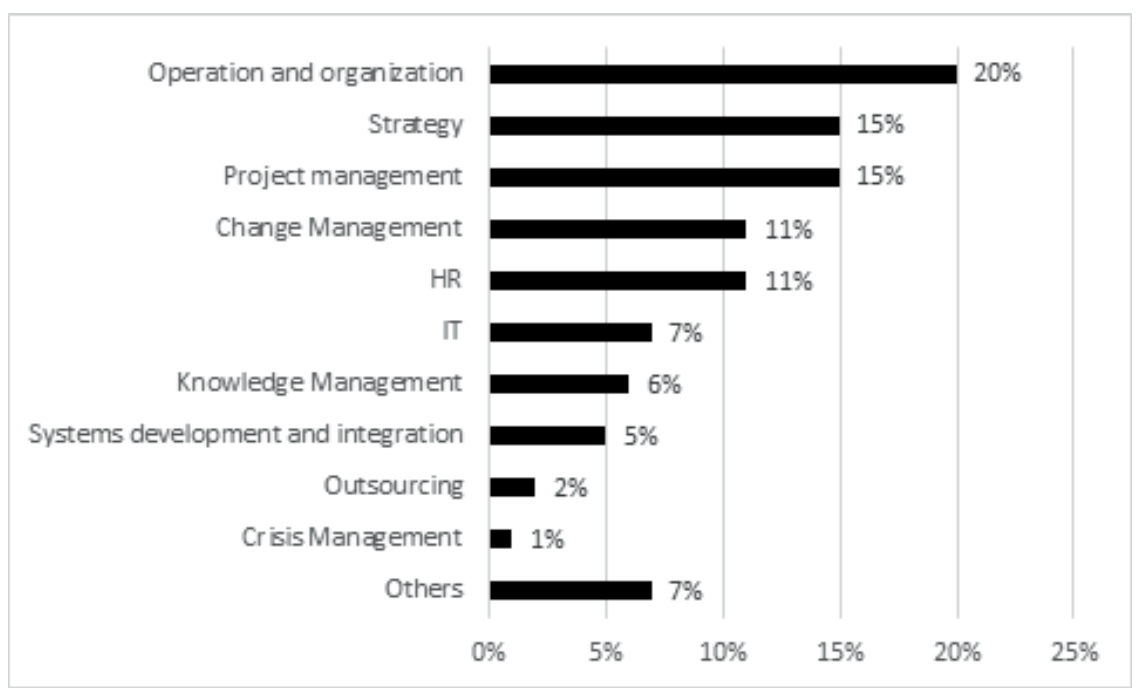

Figure 3. Most common business consulting activities in Hungary in 2015

Source: J. Poór (2015: 8).

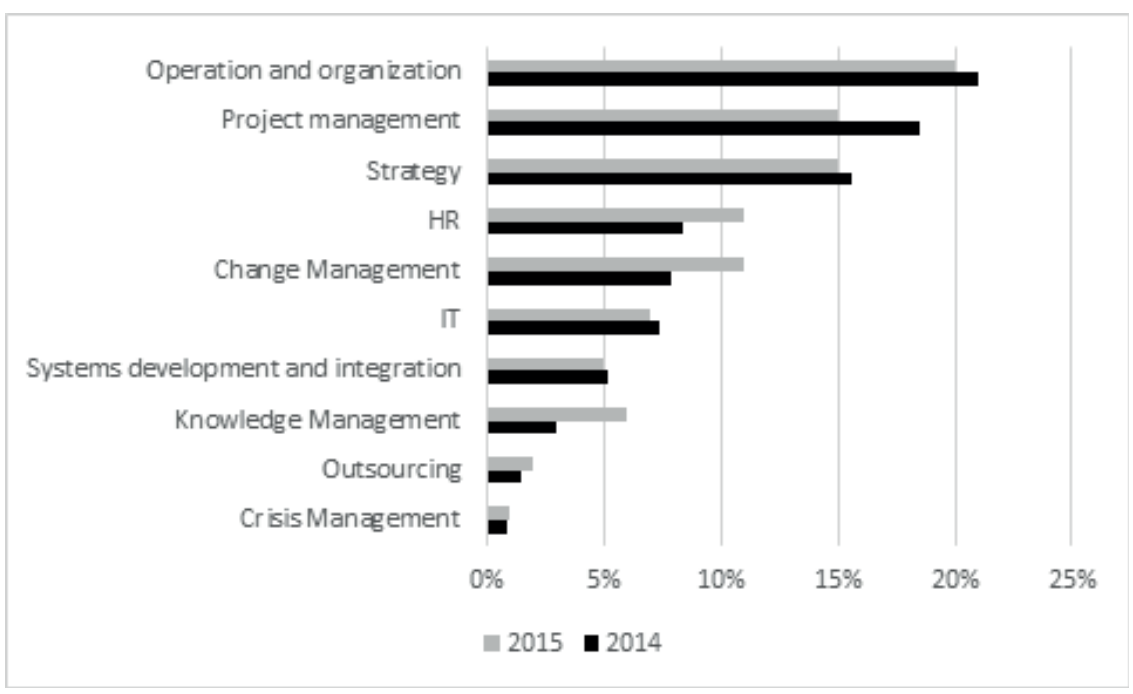

Figure 4. Most common business consulting activities in 2014-2015

Source: own calculations based on J. Poór $(2014 ; 2015)$.

sing: it decreased about one percentage point from about $16 \%$ to $15 \%$. The leading consultancy topics, such as operations consulting and project consulting also decreased. HR, change management and knowledge management increased the most.

Based on the Hungarian market size numbers from G. Vicze (2014) we can calculate the size of strategic consulting in Hungary. By calculating with $15 \%$ market share of the total market, the size of the strategic consulting market is 7.500.000.000 Hungarian Forints (which is about 24 million Euros). This gives answer to the second research question.

Strategic consulting is not only very popular among business consulting but it is offered by many consulting companies in Hungary as well, including multinational companies. The most known traditional consulting companies in Hungary are Synergon, Ernst \& Young, KPMG, Deloitte (Mártonffy, 2009). There are small private compa- 
nies and consulting entrepreneurs as well on the market. Gábor Kornai, the owner of AAM Consulting states that the hourly fees of consulting can be very different. Strategic management consulting has the highest hourly fee which can be around 300 Euros/hour (Mártonffy, 2009). Subsidiaries of the "big five" consultant companies can have even higher hourly fees. This allows to have market of the smaller companies and individual consultants as well. As there is no real guarantee on the proposals given by consultants, trust becomes a major issue.

\section{Conclusions}

No company can live without a strategy making strategic consulting a very important issue. The environment is changing rapidly, thus keeping strategies up-to-date should be a necessity. Strategic management is coping with this issue. It is not enough to have a strategy, organizations should also implement it. The surveys showed that this is not an easy task. Implementing can fail due to several issues, most importantly due to awareness, which is based on not knowing the strategy and the goals. This is mainly caused by bad communication inside an organization. Financial issues can also happen and the environment can change rapidly making the strategy outdated. All of these make strategic consulting very important among business consulting. Most Hungarian consulting firms offer at least three different business consulting services.

The current research had two research questions: (1) What is the market size of the Hungarian strategic management consulting market? The total market share of strategic consulting among business consulting in Hungary is estimated about $15 \%$. This means the total Hungarian strategic consulting market size is about 24 million Euros per year. (2) What are the main trends in the Hungarian strategic management consulting market? Data shows that strategic consulting is one of the best paying consultant roles with the highest fees. Unfortunately these fees cannot be paid by every company making consultant companies very diverse. Trust becomes a major issue on new contracts. Some of the biggest multinational companies have a high market share in Hungary. The 2014 and 2015 surveys among Hungarian companies showed that strategic management is one of the major consultancy issues in Hungary next to organizational operations and project management. Trends in the market show that the share of strategic consulting decreases lightly which can be due to market saturation. This does not affect the fact that strategic consulting still remains one of the leading consultant roles.

\section{References}

Arnold, C., Bernstein, S. C. (2006). A stratégiatervezés mint belső tanácsadás. In: S. Biswas, D. Twitchell (editor). Menedzsment tanácsadás: Teljes körü útmutató az üzletághoz. Pécs: VHE.

Bartek-Lesi, M., Bartók, I., Czakó, E., Gáspár, J., Könczöl, E., Pecze, K. (2007). Vállalati stratégia. Budapest: Alinea Kiadó. Barakonyi, K. (1999). Stratégiaalkotás I. Stratégiai tervezés. Budapest: Nemzeti Tankönyvkiadó.

Barakonyi, K. (2000). Stratégiaalkotás II. Stratégiai menedzsment. Budapest: Nemzeti Tankönyvkiadó.

Biech, E. (2006). A tanácsadás világa. Az alapoktól kezdve... Pécs: VHE.

Biswas, S., Twitchell, D. (2006). Menedzsment tanácsadás: Teljes körü útmutató az üzletághoz. Pécs: VHE.

Budapesti Kereskedelmi és Iparkamara (2014). Túljutott a válságon a menedzsment tanácsadás. http://bkik.hu/tuljutott-a-valsagon-a-menedzsment-tanacsadas/, downloaded: 13 $3^{\text {th }}$ March 2017.

CFO Magazine, Business Intelligence (1996). Translating Strategy into Action. Joint study by Renaissance Solutions Inc., CFO Magazine and Business Intelligence.

Covey, S. R., Merrill, A. R., Merrill, R. R. (1994). First Things First. New York: Fireside.

David, F. R. (2013). Strategic Management. Concepts and Cases. Fourteenth Edition. Pearson Education Limited.

Hoványi, G. (1997). Menedzsment tanácsadás. Pécs: Janus Pannonius Tudományegyetem Közgazdaságtudományi Kar. Kubr, M. (2002). Management Consulting: A Guide to the Profession. Fourth Edition. Geneva: International Labour Office.

Maria, A., Little, A. D. (2006). Tanácsadás a változásmenedzsment területén. In: S. Biswas, D. Twitchell, (editor). Menedzsment tanácsadás: Teljes körü útmutató az üzletághoz. Pécs: VHE.

Mártonffy, A. (2009). A tanácsadó és a svindler. IT Business. Available at: http://www.itbusiness.hu/Fooldal/main flash_banner/A_tanacsado_es_a_svindler.html [Accessed March 13, 2017].

MIT (2004). Careers in Strategic Management and Consulting Classes, Research, and Resources Available to MIT Sloan Students. Available at: http://web.mit.edu/sloanjapan/101/curriculum/roadmap/05_Strategic.pdf [Accessed March 13, 2017]. 
Neilson, G. L., Martin, K. L., Powers, E. (2008). The Secrets to Successful Strategy Execution. USA: Harvard Business Review. HBR's Must Reads on Strategy.

Poór, J. (2014). Menedzsment tanácsadás helyzete Magyarországon. Menedzsment és HR Kutató Központ, Szent István Egyetem, GTK TTI.

Poór, J. (2015). Menedzsment tanácsadás módszereinek változása Magyarországon. Menedzsment és HR Kutató Központ, Szent István Egyetem, GTK TTI.

Provice Kft (2017). Stratégia végrehajtási képességfejlesztés. Available at: http://www.provice.hu/Strategia_Vegrehajtasi_Kepessegfejlesztes [Accessed March 13, 2017].

Vicze, G. (2014). Versenyképességi tényezök és kitörési lehetöségek a magyar szolgáltató szektorban-a vezetési tanácsadás esete. PhD dissertation. Veszprém: Pannon Egyetem, Gazdálkodás- és Szervezéstudományok Doktori Iskola.

Wheelen, T. L., Hunger, J. D. (2012). Concepts in Strategic Management and Business Policies. Toward Global Sustainability. Thirteenth Edition. USA: Pearson Education Inc.

\section{VENGRIJOS STRATEGINIU VADYBOS KONSULTACIJU RINKOS ANALIZ它}

ROLAND SCHMUK

Pécs universitetas (Vengrija)

\section{Santrauka}

Smulkiajam ir vidutiniam Vengrijos verslui kyla problemų, kurios susijusios su vadybos metodologija. Todèl strateginès vadybos konsultacijos verslo konsultavimo praktikoje yra ịprastas dalykas ir viena svarbiausių konsultacijų sričių. Straipsnyje analizuojama Vengrijos vadybos konsultacijų rinka, remiantis dviem vengrų apklausomis, siekiant geriau suprasti vengrišką strateginès vadybos konsultavimo rinką. Dvi apklausos palygintos tarpusavyje ir vengrų strateginès vadybos konsultavimo rinka apskaičiuota iš antrinių duomenų. Glaustai apibrèžtos pramonès problemos ir pateikti rezultatai leidžia įvertinti jos padètị.

Atliekant tyrimą kelti du klausimai. (1) Koks yra strateginès vadybos konsultavimo rinkos dydis? Visa rinkos dalis, užimta strateginio konsultavimo, yra apie 15 proc. Tai reiškia, kad visos vengrų strateginio konsultavimo rinkos dydis yra apie 24 milijonus euru per metus. (2) Kokios pagrindinès vengru strateginés vadybos konsultavimo tendencijos? Duomenys rodo, kad strateginis konsultavimas konsultavimo rinkoje daugiausia apmokamas. Tačiau ne visos ịmonės gali tai sau leisti, dẻl to konsultavimo ịmonių įvairovè - didžiulè. Bendraujant su naujais užsakovais ypač svarbus tampa pasitikèjimas. Kai kurios didžiausios tarptautinės kompanijos Vengrijoje užima didelę rinkos dali. 2014 ir 2015 metų apklausos, vykdytos vengrų įmonėse, atskleide, kad strateginis vadybos konsultavimas yra viena pagrindinių konsultavimo temų Vengrijoje šalia organizacinių operacijų ir projektų vadybos. Tendencijos rodo, kad strateginio konsultavimo rinkos dalis mažèja - galbūt dèl rinkos perpildymo. Vis dèlto strateginis konsultavimas yra vienas pagrindinių konsultavimo vaidmenų.

PAGRINDINIAI ŽODŽIAI: strategija, vadyba, konsultavimas, Vengrija.

JEL KLASIFIKACIJA: L10, L21, M21

Received: 2017.03.20

Revised: 2017.04 .27

Accepted: 2017.05.02 